\title{
Preparation of highly dispersed desulfurization catalysts and their catalytic performance in hydrodesulfurization of dibenzothiophene
}

\author{
Liang Hao, Guang Xiong, Liping Liu*, Huayun Long, Fengying Jin, Xiangsheng Wang \\ State Key Laboratory of Fine Chemicals, School of Chemical Engineering, Dalian University of Technology, Dalian 116024, Liaoning, China
}

\section{A R T I C L E I N F O}

Article history:

Received 15 October 2015

Accepted 12 November 2015

Published 5 March 2016

Keywords:

Micro-mesoporous molecular sieve

ZK-1

Hydrodesulfurization

Dibenzothiophene

\begin{abstract}
A B S T R A C T
Micro-mesoporous ZK-1 molecular sieves with different $\mathrm{Si} / \mathrm{Al}$ ratios were used as supports for binary Co-Mo hydrodesulfurization (HDS) catalysts. The CoMo/ZK-1 catalysts were prepared using an over-loading impregnation method, and characterized using $\mathrm{N}_{2}$ physisorption, X-ray diffraction, temperature-programmed $\mathrm{NH}_{3}$ desorption, temperature-programmed reduction (TPR), ultraviolet-visible diffuse reflectance spectroscopy, and high-resolution transmission electron microscopy (HRTEM). The results show that the CoMo/ZK-1 catalysts have high surface areas $\left(\sim 700 \mathrm{~m}^{2} / \mathrm{g}\right)$, large pore volumes, and hierarchical porous structures, which promote the dispersion of Co and Mo oxide phases on the ZK-1 supports. The TPR results show that the interactions between the Co and Mo oxide phases and the ZK-1 support are weaker than those in the $\mathrm{CoMo} / \gamma-\mathrm{Al}_{2} \mathrm{O}_{3}$ catalyst. The HRTEM results show that the CoMo/ZK-1 catalysts have better $\mathrm{MoS}_{2}$ dispersion and more active edge sites. The catalysts were tested in HDS of dibenzothiophene. Under mild reaction conditions, the activity of Co and Mo sulfides supported on ZK-1 was higher than those of Co and Mo sulfides supported on ZSM-5, AlKIT-1, and $\gamma-\mathrm{Al}_{2} \mathrm{O}_{3}$.
\end{abstract}

(C) 2016, Dalian Institute of Chemical Physics, Chinese Academy of Sciences. Published by Elsevier B.V. All rights reserved.

\section{Introduction}

In recent years, air pollution caused by exhaust gases from diesel engines has become a serious problem. Environmental legislation is placing increasingly severe restrictions on the sulfur contents of fuels. Research on efficient deep hydrodesulfurization (HDS) catalysts is therefore a hot topic. Dibenzothiophene (DBT) and its alkyl-substituted derivatives are the most difficult components to remove from the diesel fraction because of steric hindrance [1]. In the last decade, traditional HDS catalysts have usually been based on Mo (W) sulfides promoted by $\mathrm{Co}(\mathrm{Ni})$ supported on $\gamma-\mathrm{Al}_{2} \mathrm{O}_{3}$ [2-5]. Other mesostructured materials such as MCM-41, SBA-15, HMS, KIT-1, and KIT-6 are also used as supports [6-12]. The properties of these materials are different from those of $\mathrm{Al}_{2} \mathrm{O}_{3}$. KIT- 1 is a three-dimensional mesoporous molecular sieve with a uniform pore size and high surface area. In particular, disordered KIT-1 is hydrothermally more stable than ordered MCM-41 [13]. The catalytic activity of KIT-1-supported $\mathrm{MoO}_{3}$ and/or $\mathrm{NiO}$ catalysts in thiophene HDS is higher than that of catalysts supported on MCM-41 and NaY zeolites [11].

These mesoporous materials have appropriate physicochemical properties. However, their practical application is limited because their pore walls are amorphous, resulting in relatively low acidity and thermal stability. The design and development of novel catalyst materials with large pores and suitable acidities are therefore needed. Large pores eliminate the diffusion resistance of reactant molecules, and increased acidity improves the hydrogenation and hydrogenolysis reactions of $\mathrm{C}-\mathrm{S}$ bonds in sulfides. Some studies have shown that

\footnotetext{
* Corresponding author. Tel/Fax: +86-411-84986139; E-mail: liuliping@dlut.edu.cn This work was financially supported by the National Natural Science Foundation of China (NNSFC, 21206017). DOI: 10.1016/S1872-2067(15)61017-8 | http://www.sciencedirect.com/science/journal/18722067 | Chin. J. Catal., Vol. 37, No. 3, March 2016
} 
because of the high adsorption potential of micropores, some micro-mesoporous molecular sieves can adsorb $\mathrm{H}_{2}$ molecules effectively. This reduces the energy cost and improves the catalyst efficiency under mild reaction conditions [14]. Micro-mesoporous materials, including Y-MCM-41, $\beta$-MCM-41, mesoporous ZSM-5, mesoporous $\beta$, $\beta$-KIT-6, and L-SBA-15, have been synthesized and tested in HDS reactions [7,15-19]. Sun and Prins [19] reported high activities in the HDS of 4,6-dimethyldibenzothiophene (4,6-DMDBT) over noble metals supported on mesoporous ZSM-5 zeolites. The catalytic activity of $\beta$-MCM-41-supported NiW HDS catalyst was higher than that of the $\mathrm{Al}_{2} \mathrm{O}_{3}$-supported catalyst [15]. Li et al. [7] prepared MCM-41/HY composite materials (MY); NiMo/MY catalysts showed higher HDS activities and reducibilities than $\mathrm{Ni}$ Mo/MCM-41. We previously reported the direct hydrothermal synthesis of ZSM-5/KIT-1 micro-mesoporous molecular sieves (denoted by ZK-1) by one-step crystallization using dual templates $[20,21]$. No precursor crystallization is required, which prevents overgrowth of the precursors before the final crystallization step. The framework structure, porosity, and morphology of ZK-1 can be well controlled by simply varying the crystallization temperature $\left(90-170{ }^{\circ} \mathrm{C}\right)$. The surface area, pore volume, hydrothermal stability, and acidity of ZK-1 are higher than those of KIT-1.

In the present work, ZK-1-supported CoMo catalysts were prepared and tested in the HDS of DBT. The effects of the support properties on the catalytic performance were clarified by comparison with other catalysts, namely CoMo catalysts supported on ZSM-5, AlKIT- 1 , and commercial $\gamma-\mathrm{Al}_{2} \mathrm{O}_{3}$. The catalysts were characterized using X-ray diffraction (XRD), highresolution transmission electron microscopy (HRTEM), $\mathrm{N}_{2}$ adsorption, temperature-programmed $\mathrm{NH}_{3}$ desorption $\left(\mathrm{NH}_{3}\right.$ TPD), temperature-programmed $\mathrm{H}_{2}$ reduction $\left(\mathrm{H}_{2}-\mathrm{TPR}\right)$, and ultraviolet-visible diffuse reflectance spectroscopy (UV-VisDRS). HDS of DBT was used as a test reaction for comparison of the catalytic performance of six different catalysts.

\section{Experimental}

\subsection{Preparation of ZK-1 support}

ZK-1 was synthesized using a previously reported direct method [20]. The experimental procedure was as follows. (1) Aluminum isopropoxide was added to an aqueous solution of tetrapropylammonium hydroxide (TPAOH). The mixture was stirred at $0{ }^{\circ} \mathrm{C}$ until a clear solution was formed, and then tetraethylorthosilicate was added. The mixture was stirred at room temperature for several hours. (2) A mixture of cetyltrimethylammonium bromide (CTAB) and deionized water was added to the aluminosilicate precursor. The molar composition was 60 (or 80 ) $\mathrm{SiO}_{2}: \mathrm{Al}_{2} \mathrm{O}_{3}: 15 \mathrm{TPAOH}: 15 \mathrm{CTAB}: 1000 \mathrm{H}_{2} \mathrm{O}$. The resulting mixture was transferred to a stainless-steel autoclave. (3) After hydrothermal crystallization for $48 \mathrm{~h}$ at $130{ }^{\circ} \mathrm{C}$, the solid product was removed by filtration, washed with water, and dried at $80^{\circ} \mathrm{C}$ for $12 \mathrm{~h}$. (4) The samples were calcined at $550{ }^{\circ} \mathrm{C}$ for $10 \mathrm{~h}$ to give the final products $\mathrm{ZK}-1(30)(\mathrm{Si} / \mathrm{Al}=30)$ and $\mathrm{ZK}-1(40)(\mathrm{Si} / \mathrm{Al}=40)$.
AlKIT-1 (Si/Al = 30) was prepared using a method described in the literature [13]. $\gamma-\mathrm{Al}_{2} \mathrm{O}_{3}$ and $\mathrm{ZSM}-5$ (Si/Al = 35) are industrial catalysts. The support Mix was a mechanical mixture of equal amounts of AlKIT-1 and ZSM-5.

\subsection{Catalyst preparation}

H-type AlKIT-1 and ZSM-5 materials were obtained by ion exchange with $\mathrm{NH}_{4} \mathrm{NO}_{3}$ aqueous solution (0.4 mol/L) for $6 \mathrm{~h}$ (three times). The products were washed and dried at $100{ }^{\circ} \mathrm{C}$, and calcined at $500{ }^{\circ} \mathrm{C}$ for $4 \mathrm{~h}$. The corresponding catalysts on different supports (ZK-1, $\gamma-\mathrm{Al}_{2} \mathrm{O}_{3}, \mathrm{ZSM}-5$, AlKIT-1, and Mix) were prepared by co-impregnation with ammonium molybdate and cobalt nitrate. The samples were dried overnight at $100{ }^{\circ} \mathrm{C}$ and calcined at $500{ }^{\circ} \mathrm{C}$ for $3 \mathrm{~h}$. The resulting catalysts, containing $20 \mathrm{wt} \% \mathrm{MoO}_{3}$ and $6.94 \mathrm{wt} \% \mathrm{CoO}$, were denoted by CoMo/ZK-1(30), CoMo/ZK-1(40), CoMo $/ \gamma-\mathrm{Al}_{2} \mathrm{O}_{3}$, CoMo/AlKIT-1, CoMo/ZSM-5, and CoMo/Mix.

\subsection{Catalyst characterization}

XRD patterns of the supports and catalysts were obtained using a Rigaku D/Max 2400 diffractometer with a Ni-filtered $\mathrm{Cu}$ $K_{\alpha} \mathrm{X}$-ray source at a scanning rate of $0.02^{\circ} / \mathrm{s}$. The $2 \theta$ range was $5^{\circ}-80^{\circ}$ for wide-angle scans and $0.5^{\circ}-10^{\circ}$ for small-angle scans.

$\mathrm{N}_{2}$ adsorption-desorption isotherms were obtained using a Quantachrome AUTOSORB-1-MP apparatus at liquid $\mathrm{N}_{2}$ temperature $\left(-196^{\circ} \mathrm{C}\right)$. The samples were degassed at $350{ }^{\circ} \mathrm{C}$ prior to analysis. The mesoporous structure was determined from the adsorption branch of the isotherms using the Barrett-Joyner-Halenda model. The microporous distribution was calculated using the Horvath-Kawazoe model.

$\mathrm{NH}_{3}$-TPD was performed using a ChemBET 3000 chemisorption instrument (Quantachrome). The effluent stream was monitored continuously using a thermal conductivity detector (TCD) to determine the rate of $\mathrm{NH}_{3}$ desorption.

$\mathrm{H}_{2}$-TPR was performed using a ChemBET 3000 chemisorption instrument. The amount of sample used for each measurement was $0.1 \mathrm{~g}$. The samples were pretreated with $\mathrm{Ar}$ at 20 $\mathrm{mL} / \mathrm{min}$, heated at $5{ }^{\circ} \mathrm{C} / \mathrm{min}$ to $500{ }^{\circ} \mathrm{C}$, and held at this temperature for $1 \mathrm{~h}$. The temperature was lowered to $80^{\circ} \mathrm{C}$, the $\mathrm{Ar}$ flow was switched to a $10 \% \mathrm{H}_{2} / \mathrm{Ar}$ flow, and the samples were heated to $1000{ }^{\circ} \mathrm{C}$ at $10^{\circ} \mathrm{C} / \mathrm{min}$. The effluent gas was analyzed using a TCD.

UV-Vis spectra were obtained from 190 to $800 \mathrm{~nm}$ using a Jasco UV-550 spectrometer; pure $\mathrm{BaSO}_{4}$ was used as a reference.

HRTEM images of the sulfided catalysts were obtained using a Philips Tecnai G2 F20 transmission electron microscope operated at an accelerating voltage of $200 \mathrm{kV}$. The samples were suspended and dispersed on a grid. The solid samples were ultrasonically dispersed in ethanol, and test samples were prepared by dropping the dispersed suspensions on carbon-coated copper grids.

\subsection{Catalytic activity measurements}


The catalytic activity of the catalysts were investigated using DBT as the probe reactant, because HDS of DBT is widely used as a model reaction for studying deep HDS of diesel fuels. The reactions were performed in a continuous fixed-bed reactor using $0.5 \mathrm{~g}$ of catalyst. All the catalysts were presulfided in situ with $3.0 \mathrm{wt} \% \mathrm{CS}_{2}$ - cyclohexane and $\mathrm{H}_{2}$ mixture at $290{ }^{\circ} \mathrm{C}$ and 3 $\mathrm{MPa}$. The activity tests were performed at $320^{\circ} \mathrm{C}$ and $3.0 \mathrm{MPa}$, with $\mathrm{H}_{2}$ /oil ratio of 300 . The sulfur contents of the feed and product were determined using a ZWK-2001 PC sulfur chlorine analyzer (Jiangyan Gaoke Analysis Instruments Ltd., China). The catalytic activity was estimated as the HDS efficiency, which is defined as: HDS efficiency $=\left[\left(S_{\mathrm{f}}-S_{\mathrm{p}}\right) / S_{\mathrm{f}}\right] \times 100 \%$, where $S_{\mathrm{f}}$ and $S_{\mathrm{p}}$ are the sulfur concentrations in the feed and product, respectively.

\section{Results and discussion}

\section{1. $X R D$ results}

The XRD patterns of the catalysts are shown in Fig. 1. Fig. 1(a) shows the small-angle XRD patterns. Samples (1), (2), (4), and (6) give peaks at $2 \theta=2^{\circ}-3^{\circ}$ and $2 \theta=4.5^{\circ}$, corresponding to the (100) and (200) planes of KIT-1, respectively [20]. The presence of these peaks indicates that the mesopores of KIT-1 remained after impregnation and calcination.

Fig. 1(b) shows the wide-angle XRD patterns. The ZSM-5 zeolite and Mix catalyst patterns both have peaks at $2 \theta=7.7^{\circ}$ and $8.6^{\circ}$, which are characteristic of zeolite ZSM-5 [22]. However, these peaks are absent from the patterns for samples (1) and (2), suggesting the absence of segregated microporous ZSM-5 crystals or that the amount is below the detection limit. Samples (1), (2), and (4) give weak peaks at $2 \theta=27.3^{\circ}$, indicating small amounts of $\mathrm{MoO}_{3}$ crystalline phases. The peaks at $2 \theta=$ $23.4^{\circ}$ and $26.5^{\circ}$ are assigned to $\beta-\mathrm{CoMoO}_{4}$ crystallites [23]. For the $\mathrm{CoMo} / \mathrm{Al}_{2} \mathrm{O}_{3}$ catalyst, the peaks at $2 \theta=37.9^{\circ}, 45.9^{\circ}$, and $66.8^{\circ}$ are associated with $\gamma-\mathrm{Al}_{2} \mathrm{O}_{3}$ [24]. No obvious peaks at $2 \theta=$ $23.4^{\circ}, 26.5^{\circ}$, and $27.3^{\circ}$ from $\mathrm{CoMoO}_{4}$ and $\mathrm{MoO}_{3}$ crystals are detected in the pattern of the $\mathrm{CoMo} / \mathrm{Al}_{2} \mathrm{O}_{3}$ catalyst, implying that $\mathrm{MoO}_{3}$ and $\mathrm{CoO}$ are highly dispersed on the support. Samples (5) and (6) both give an intense peak corresponding to

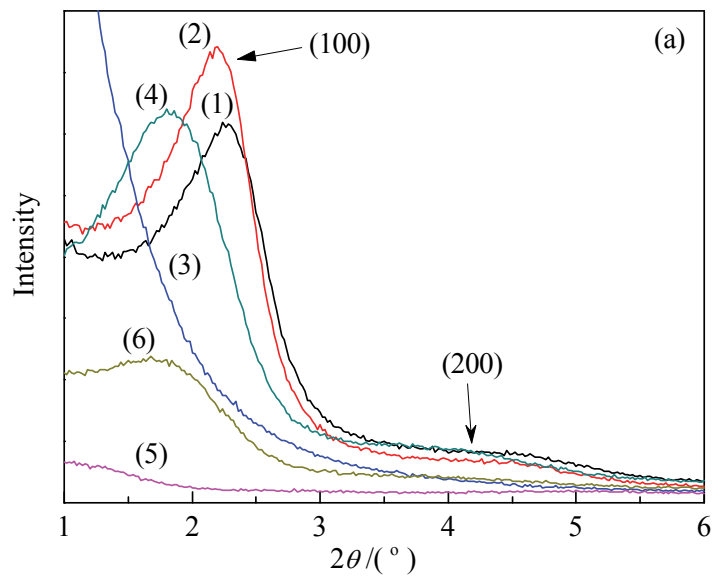

Fig. 1. Small-angle (a) and wide-angle (b) XRD patterns of the catalysts. Mo/AlKIT-1; (5) CoMo/ZSM-5; (6) CoMo/Mix. crystalline $\mathrm{MoO}_{3}$, indicating that the distribution of $\mathrm{MoO}_{3}$ is not homogeneous.

\section{2. $\mathrm{N}_{2}$ adsorption isotherms}

The $\mathrm{N}_{2}$ adsorption-desorption isotherms of the supported catalysts are shown in Fig. 2(a). The adsorption and desorption curves of samples (3) and (4) show typical type IV isotherms. Sample (5) has a type I isotherm, corresponding to a microporous material. Samples (1), (2), and (6) have characteristics similar to type IV and I isotherms. The initial increase in the adsorbed volume at low pressure is the result of monolayer adsorption in micropores. Samples (1) and (2) show steep increases in their curves at a relative pressure $p / p_{0}<0.01$; this is caused by filling of the micropores. A further increase in the adsorbed volume occurs at $p / p_{0}=0.2-0.3$ for samples (1), (2), (4), and (6); this indicates capillary condensation. In the isotherms of sample (3), the inflection appears at a higher $p / p_{0}$. This suggests that the average mesopore size of sample (3) is larger, which is consistent with the mesoporous pore size distribution results. The pore size distributions obtained from the adsorption isotherms are shown in Fig. 2(b) and (c). There are no mesopores in sample (5), which is supported on ZSM-5. The average mesopore size of samples (1) and (2) is $2.3 \mathrm{~nm}$, which is slightly smaller than that of $2.5 \mathrm{~nm}$ for samples (4) and (6).

Table 1 shows the textural and structural properties of the supported catalysts. Samples (1) and (2) have the highest surface areas ( $\left.700 \mathrm{~m}^{2} / \mathrm{g}\right)$, followed by samples (4) $\left(522 \mathrm{~m}^{2} / \mathrm{g}\right)$ and (6) (417 $\left.\mathrm{m}^{2} / \mathrm{g}\right)$. The pore size distributions of samples (1) and (2) are special because the ZK-1 support has the mesoporous structure of KIT-1 and zeolite building units [19]. However, ZK-1 is not a mixture of KIT-1 and ZSM-5. The specific surface areas and pore volumes of samples (3) and (5) are smaller than those of the other samples. This is because of the smaller surface areas and pore volumes of the supports, i.e., $\gamma-\mathrm{Al}_{2} \mathrm{O}_{3}$ and ZSM-5.

\subsection{Acidic properties}

Fig. 3 shows $\mathrm{NH}_{3}$-TPD profiles of the supported catalysts.

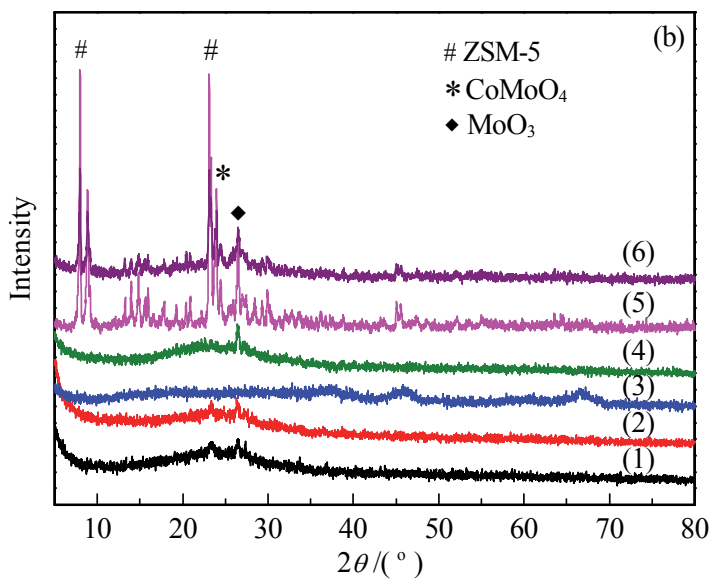

(1) CoMo/ZK-1(30); (2) CoMo/ZK-1(40); (3) CoMo/ $/-\mathrm{Al}_{2} \mathrm{O}_{3}$; (4) Co- 

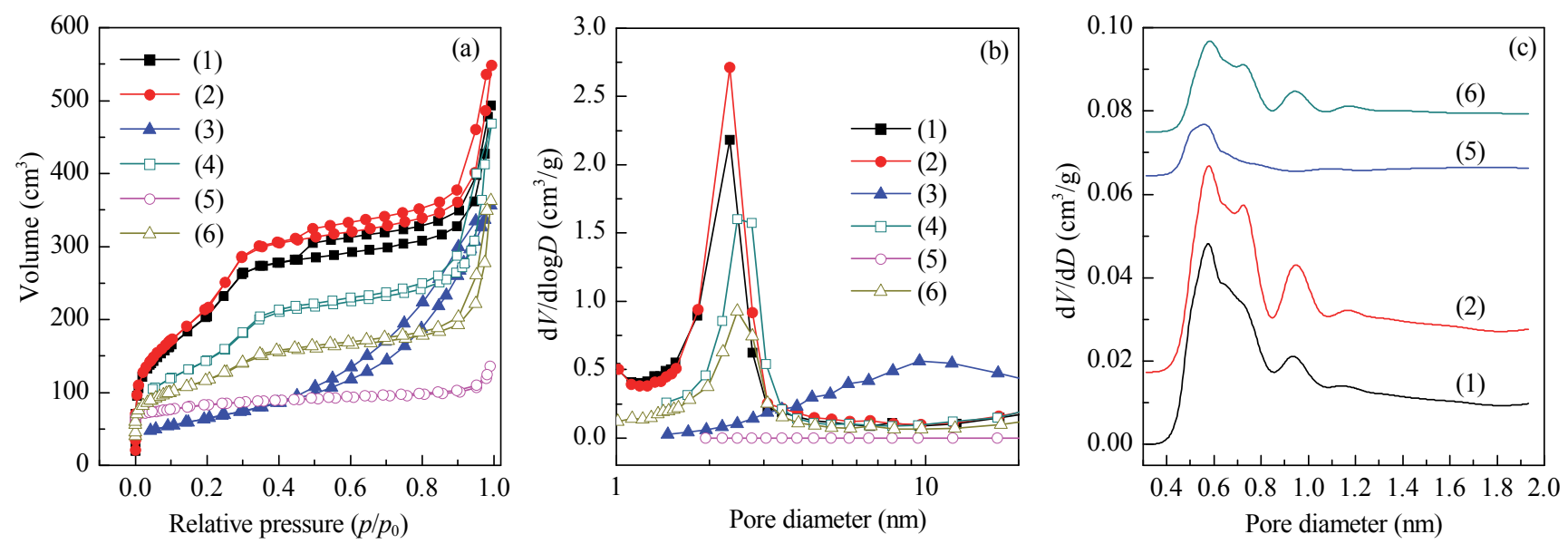

Fig. 2. $\mathrm{N}_{2}$ adsorption-desorption isotherms (a), mesopore size distributions (b), and micropore size distributions (c) of the catalysts. (1) CoMo/ZK-1(30); (2) CoMo/ZK-1(40); (3) CoMo/ $\gamma-\mathrm{Al}_{2} \mathrm{O}_{3}$; (4) CoMo/AlKIT-1; (5) CoMo/ZSM-5; (6) CoMo/Mix.

The peak temperature represents the acidic strength and the peak intensity represents the amount of acidic centers. The TPD profiles of the catalysts contain a single peak at about 250 ${ }^{\circ} \mathrm{C}$. The total acidities, derived from the $\mathrm{NH}_{3}$-TPD profile areas, decrease in the order CoMo/ZK-1(30) > CoMo/AlKIT- $1>$ Co$\mathrm{Mo} / \mathrm{ZK}-1(40)>\mathrm{CoMo} / \mathrm{Mix}>\mathrm{CoMo} / \gamma-\mathrm{Al}_{2} \mathrm{O}_{3}>\mathrm{CoMo} / \mathrm{ZSM}-5$. The area of the desorption peak of CoMo/ZK-1(30) is clearly larger than that of CoMo/AlKIT-1, which has the same Si/Al ratio. This is because the introduction of microporous structures into the mesoporous material increases the amount of acidic sites and the acidic strength of the catalyst.

\section{4. $\mathrm{H}_{2}$-TPR properties}

TPR was used to obtain information on the interactions between the supported phase and the carrier. The TPR profiles of the calcined samples are shown in Fig. 4. The profiles of samples (1) and (2) (CoMo/ZK-1) have three peaks, at 543, 604, and $810{ }^{\circ} \mathrm{C}$, with the same $\mathrm{H}_{2}$ consumption distributions. According to previous studies $[24,25]$, the two overlapping peaks in the $500-650{ }^{\circ} \mathrm{C}$ region indicate the coexistence of octahedral Mo species with different degrees of agglomeration. The lowtemperature reduction peaks are assigned to the first step of Mo reduction $\left(\mathrm{Mo}^{6+}+2 \mathrm{e}^{-} \rightarrow \mathrm{Mo}^{4+}\right)$ in polymeric octahedral species. The high-temperature reduction peak at around $810^{\circ} \mathrm{C}$ is associated with complete reduction $\left(\mathrm{Mo}^{4+}+2 \mathrm{e}^{-} \rightarrow \mathrm{Mo}^{0}\right)$ of polymeric octahedral and tetrahedral Mo species, or reduction

Table 1

Textural properties of the catalysts.

\begin{tabular}{lccccc}
\hline Sample a & $\begin{array}{c}\text { Surface } \\
\text { area } \\
\left(\mathrm{m}^{2} / \mathrm{g}\right)\end{array}$ & $\begin{array}{c}\text { Micropore } \\
\text { surface area } \\
\left(\mathrm{m}^{2} / \mathrm{g}\right)\end{array}$ & $\begin{array}{c}\text { Micropore } \\
\text { size } \\
(\mathrm{nm})\end{array}$ & $\begin{array}{c}\text { Mesopore } \\
\text { size } \\
(\mathrm{nm})\end{array}$ & $\begin{array}{c}\text { Pore } \\
\text { volume } \\
\left(\mathrm{cm}^{3} / \mathrm{g}\right)\end{array}$ \\
\hline$(1)$ & 699 & 574 & $0.6-1$ & 2.3 & 0.76 \\
$(2)$ & 730 & 586 & $0.6-1$ & 2.3 & 0.85 \\
$(3)$ & 230 & 0 & - & 10 & 0.55 \\
$(4)$ & 522 & 395 & - & 2.5 & 0.72 \\
$(5)$ & 299 & 265 & $0.5-0.6$ & - & 0.21 \\
$(6)$ & 417 & 324 & $0.6-1$ & 2.5 & 0.56
\end{tabular}

a (1) CoMo/ZK-1(30); (2) CoMo/ZK-1(40); (3) CoMo/ $/-\mathrm{Al}_{2} \mathrm{O}_{3}$; (4) CoMo/AlKIT-1; (5) CoMo/ZSM-5; (6) CoMo/Mix. of Mo species that strongly interact with the support. Sample (4) has similar characteristics to samples (1) and (2), but the low-temperature reduction peak shifts to lower temperature

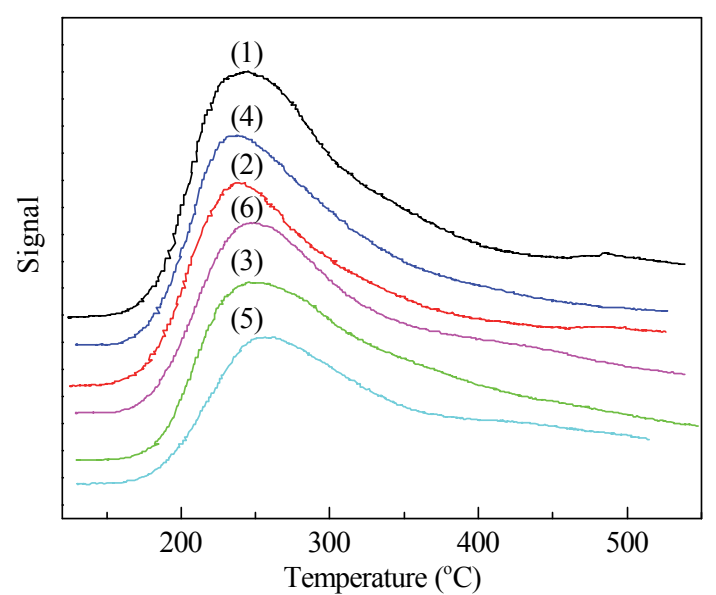

Fig. 3. $\mathrm{NH}_{3}-\mathrm{TPD}$ curves of the catalysts. (1) CoMo/ZK-1(30); (2) CoMo/ZK-1(40); (3) CoMo/ $\gamma-\mathrm{Al}_{2} \mathrm{O}_{3}$; (4) CoMo/AlKIT-1; (5) CoMo/ZSM-5; (6) CoMo/Mix.

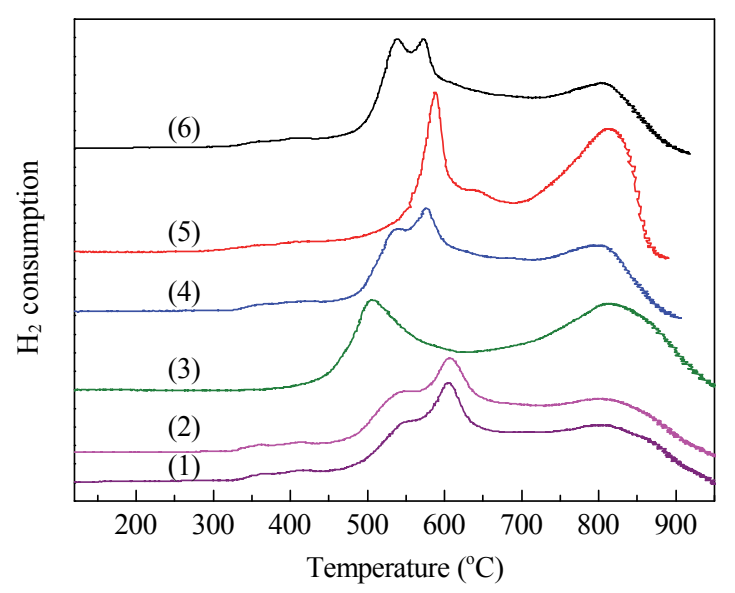

Fig. 4. TPR profiles of the catalysts. (1) CoMo/ZK-1(30); (2) CoMo/ZK-1(40); (3) CoMo/ $\gamma-\mathrm{Al}_{2} \mathrm{O}_{3}$; (4) CoMo/AlKIT-1; (5) CoMo/ZSM-5; (6) CoMo/Mix. 
(from $604{ }^{\circ} \mathrm{C}$ to $575{ }^{\circ} \mathrm{C}$ ). The profiles of samples (3) and (6) have two peaks, in the ranges $450-650{ }^{\circ} \mathrm{C}$ and $700-900{ }^{\circ} \mathrm{C}$. The reduction temperature of the low-temperature peak is lower and the hydrogen consumption in the high-temperature peak region is higher for $\mathrm{CoMo} / \gamma-\mathrm{Al}_{2} \mathrm{O}_{3}$ than for the other samples. This can be explained as follows. The reduction of octahedral $\mathrm{Mo}^{6+}$ to $\mathrm{Mo}^{4+}$ is easier, but the strong interactions via Al-Mo linkages make it more difficult to completely reduce and sulfide Mo species on $\gamma-\mathrm{Al}_{2} \mathrm{O}_{3}$.

\subsection{UV-Vis-DRS}

The changes in the electronic spectra of the samples reflect the changes in the coordination structure of Co and Mo. According to the literature [26,27], tetrahedral Mo species show absorption at 220-250 $\mathrm{nm}$, whereas octahedral Mo species show transitions at 250-330 nm. Absorption at about 400 and $750 \mathrm{~nm}$ is characteristic of octahedral $\mathrm{Co}^{2+}$ species, and a broad band centered at about $600 \mathrm{~nm}$ is associated with tetrahedral Co ions $[23,28,29]$. An octahedral component indicates the presence of $\mathrm{CoMoO}_{4}$ species, whereas the presence of tetrahedral coordinated $\mathrm{Co}^{2+}$ species indicates the formation of $\mathrm{Co}_{2} \mathrm{AlO}_{4}$ or $\mathrm{Co}_{2} \mathrm{SiO}_{4}$ via interactions of Co species with the support [27].

The UV-Vis DRS of the catalysts are shown in Fig. 5. The spectra of samples (1) and (2) (CoMo/ZK-1) show absorption from tetrahedral Mo and octahedral Mo species at 220-330 nm. No visible absorption from cobalt oxide is present at 400-700 $\mathrm{nm}$, but a weak band is observed at $750 \mathrm{~nm}$. This octahedral component indicates the presence of $\mathrm{CoMoO}_{4}$ species, as confirmed by the XRD results. Similar results are observed for Mo supported on AlKIT-1 (sample (4)). Sample (4) also shows relatively weak absorption by $\mathrm{Co}^{2+}$ at about $600 \mathrm{~nm}$. Compared with these three catalysts, catalysts (3), (5), and (6) have wider and stronger absorptions at $280-330 \mathrm{~nm}$. This may be caused by formation of a large amount of polymeric molybdate species on the supports. Fig. 5 clearly shows that the intensities of the absorptions of the tetrahedral $\mathrm{Co}^{2+}$ species at about $600 \mathrm{~nm}$ are larger for samples (3) and (5). This is probably the result of the

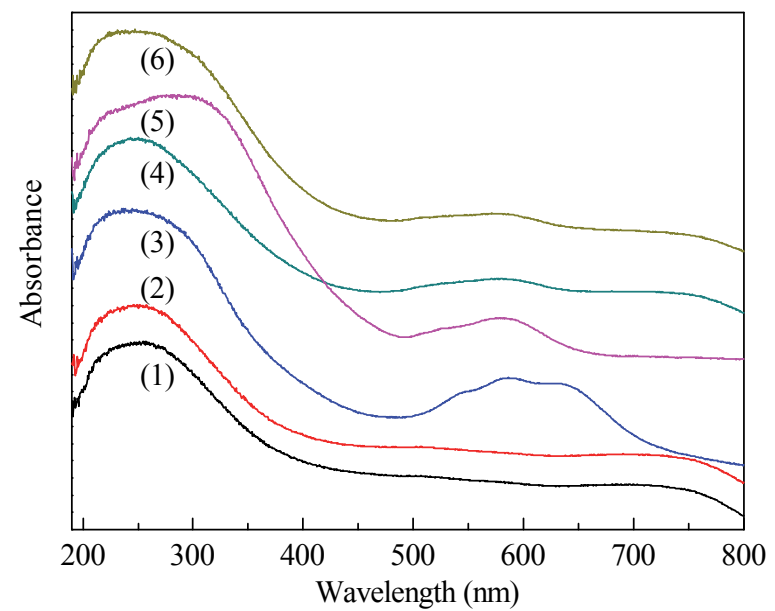

Fig. 5. UV-Vis spectra of the catalysts. (1) CoMo/ZK-1(30); (2) CoMo/ZK-1(40); (3) CoMo/ $\gamma-\mathrm{Al}_{2} \mathrm{O}_{3}$; (4) CoMo/AlKIT-1; (5) CoMo/ZSM-5; (6) CoMo/Mix. formation of large amounts of catalytically inactive $\mathrm{Co}_{2} \mathrm{AlO}_{4}$ or $\mathrm{Co}_{2} \mathrm{SiO}_{4}$ on the $\gamma-\mathrm{Al}_{2} \mathrm{O}_{3}$ and ZSM-5 surfaces.

\subsection{HRTEM results}

HRTEM is the most effective technique for examining the morphology of active phases, by visualizing $\mathrm{MoS}_{2}$ crystallite slabs on the support. Figs. 6 and 7 show representative HRTEM micrographs and the statistical results, respectively, for various sulfided catalysts. All the images show thread-like fringes corresponding to $\mathrm{MoS}_{2}$ slabs with interplanar distances of $0.61 \mathrm{~nm}$ [30]. The particles of promoter Co species on the sulfided catalysts are too small to be visualized, because of the low loading of Co species. A quantitative comparison was made by determining the lengths and layer numbers of the $\mathrm{MoS}_{2}$ slabs on the sulfided catalysts by statistical analyses based on about $30 \mathrm{mi}$ crographs including at least 300 slabs taken from different parts of each catalyst. The average slab length $\bar{L}$ and stacking number $\bar{N}$ were calculated according to Eq. (1):

$$
\bar{L}(\bar{N})=\frac{\sum_{i=1}^{n} x_{i} M_{i}}{\sum_{i=1}^{n} x_{i}}
$$

where $M_{i}$ is the slab length or stacking layer number of a stacked $\mathrm{MoS}_{2}$ unit, and $x_{i}$ is the number of slabs or stacks in a certain range of length or stacking layer number [30]. For the

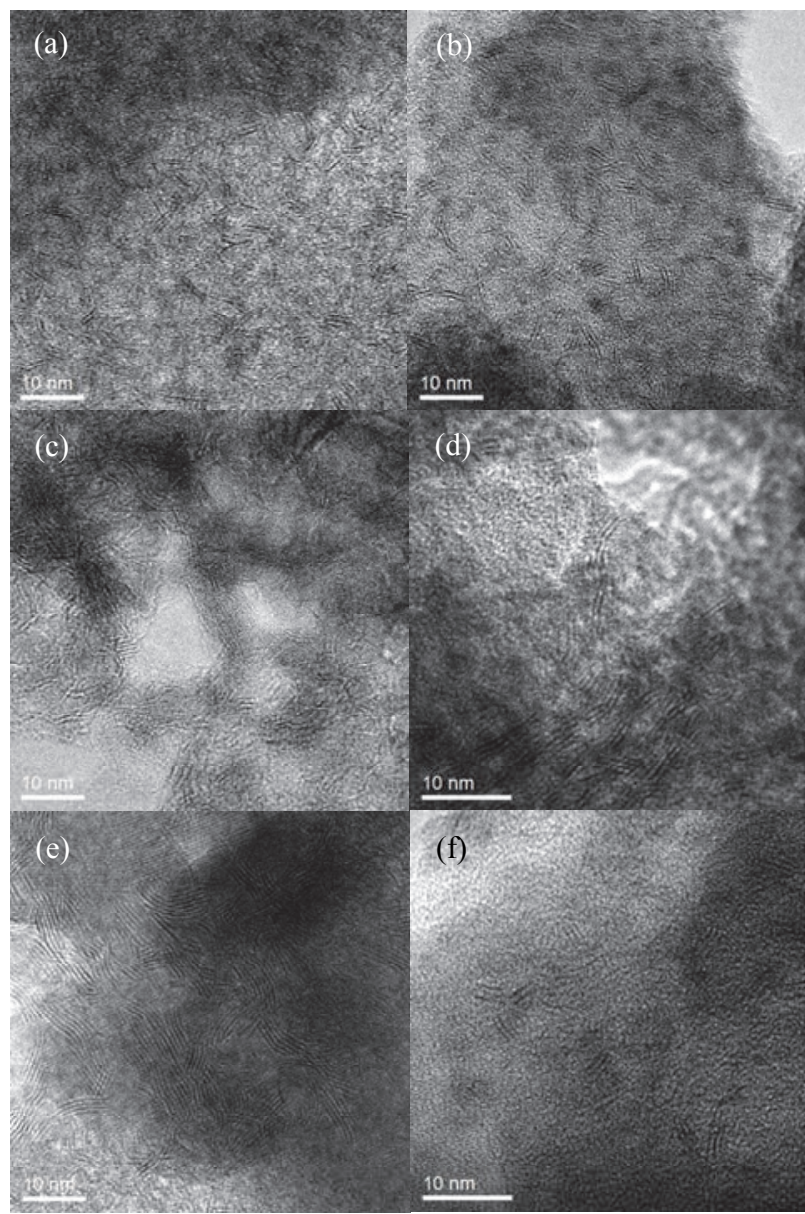

Fig. 6. HRTEM images of the sulfided catalysts. (a) CoMo/ZK-1(30); (b) CoMo/ZK-1(40); (c) CoMo/ $\gamma-\mathrm{Al}_{2} \mathrm{O}_{3}$; (d) CoMo/AlKIT-1; (e) CoMo/ZSM5; (f) CoMo/Mix. 

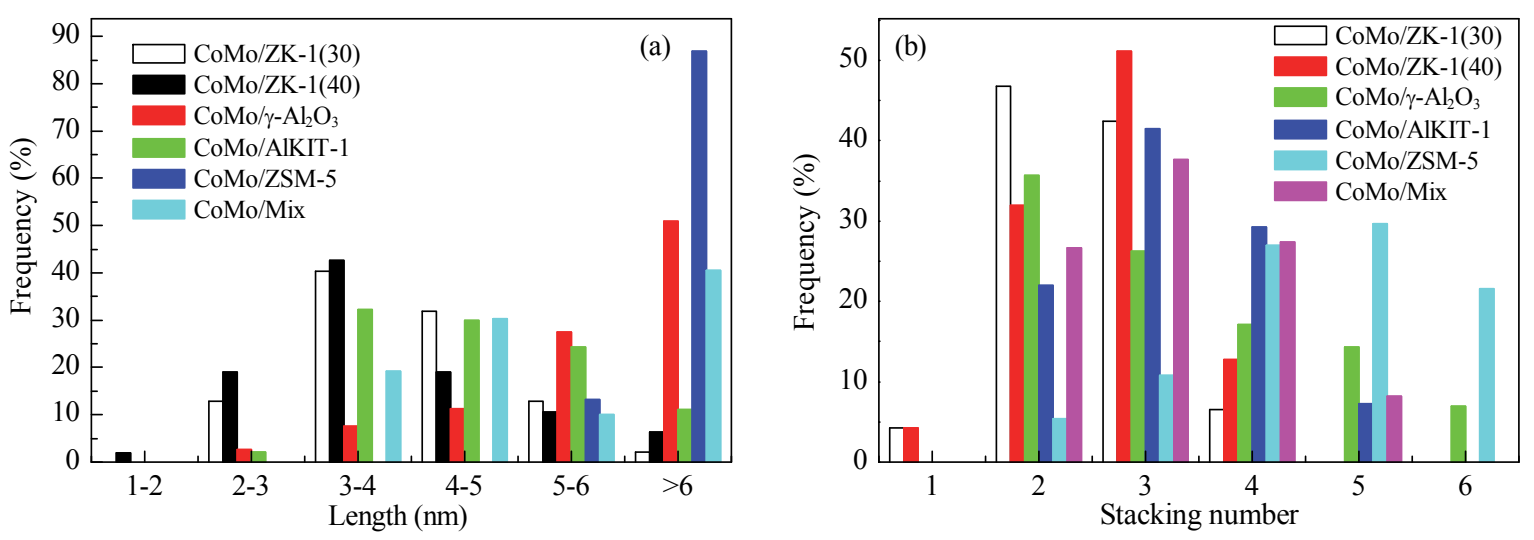

Fig. 7. Distributions of lengths (a) and layer numbers (b) of $\mathrm{MoS}_{2}$ slabs on various catalysts.

supported $\mathrm{MoS}_{2}$ HDS catalysts, Eq. (2),

$$
f_{\mathrm{Mo}}=\frac{\mathrm{Mo}_{\text {edge }}}{\mathrm{Mo}_{\text {total }}}=\frac{\sum_{i=1}^{t}\left(6 n_{i}-6\right)}{\sum_{i=1}^{t}\left(3 n_{i}{ }^{2}-n_{i}+1\right)}
$$

which is widely used to estimate the relative proportions of Mo atoms per crystallite, gives a good estimate of the turnover frequency [31]. In Eq. (2), $n_{i}$ is the number of Mo atoms along one side of a $\mathrm{MoS}_{2}$ slab, determined from its length $(\bar{L}=$ $\left.0.32\left(2 n_{i}-1\right), \mathrm{nm}\right)$, and $t$ is the total number of slabs shown in the HRTEM micrograph. It is assumed that all the edge sites are active in HDS, therefore the real value of $f_{\text {Mo }}$ could be higher than that estimated from Eq. (2).

It can be observed that the $\mathrm{MoS}_{2}$ phases on different supports differ significantly from each other. $\mathrm{MoS}_{2}$ is more evenly dispersed on ZK-1 than on other supports. Good dispersion of the active metals creates a large number of accessible active sites. The catalysts $\mathrm{CoMo} / \mathrm{Al}_{2} \mathrm{O}_{3}$ and $\mathrm{CoMo} / \mathrm{ZSM}-5$ have high degrees of stacking and long lengths because of the small surface areas of the supports. Based on the statistical results in Table 2, the $\bar{N}$ values of the $\mathrm{MoS}_{2}$ slabs of different catalysts increase in the order CoMo/ZK-1(30) < CoMo/ZK-1(40) < CoMo/AlKIT- 1 < CoMo/Mix < $\mathrm{CoMo} / \mathrm{Al}_{2} \mathrm{O}_{3}<\mathrm{CoMo} / \mathrm{ZSM}-5$; the order of the $\bar{L}$ values is CoMo/ZK-1(40) < CoMo/ZK-1(30) < CoMo/AlKIT- $1<\mathrm{CoMo} / \mathrm{Mix}<\mathrm{CoMo} / \mathrm{Al}_{2} \mathrm{O}_{3}<\mathrm{CoMo} / \mathrm{ZSM}-5$. The

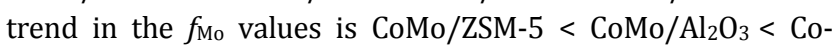
Mo/Mix < CoMo/AlKIT-1 < CoMo/ZK-1(30) < CoMo/ZK-1(40). The shortest length, lowest stacking number, and largest $f_{\text {Mo }}$ value for $\mathrm{MoS}_{2}$ particles are obtained over CoMo/ZK-1, confirming that CoMo/ZK-1 shows better $\mathrm{MoS}_{2}$ dispersion and has more active edge sites. Compared with CoMo/ZK-1(30), the high stacking number (2.7 layers) and relatively short slab length $(3.88 \mathrm{~nm})$ of the $\mathrm{MoS}_{2}$ crystallites on CoMo/ZK-1(40) result in the creation of more available edge and corner sites, enabling the incorporation of more promoter atoms into the structure of the type II Co-Mo-S phase. This is because of the different aluminum contents in the ZK-1 framework, which results in varying degrees of metal-support interactions. Suitable metal-support interactions improve dispersion and sulfidation of oxidic Mo, and this improves the HDS activity of catalysts. Although the specific surface area of CoMo/ZSM-5 (299 $\left.\mathrm{m}^{2} / \mathrm{g}\right)$ is greater than that of $\mathrm{CoMo} / \mathrm{Al}_{2} \mathrm{O}_{3}\left(230 \mathrm{~m}^{2} / \mathrm{g}\right)$, CoMo/ZSM-5 has higher values of $\bar{N}$ and $\bar{L}$ because of the small external surface area of ZSM-5. Highly stacked $\mathrm{MoS}_{2}$ crystallites are unfavorable for HDS reactions. In addition, $\mathrm{MoS}_{2}$ crystals are homogeneously distributed in $\mathrm{CoMo} / \mathrm{Al}_{2} \mathrm{O}_{3}$ because of the strong interaction between oxidic Mo and Co species and Al-OH on the support, as confirmed by the $\mathrm{H}_{2}$-TPR results.

\subsection{Catalytic properties}

The catalytic performance of a series of CoMo catalysts on different support materials, namely ZK- $1, \gamma-\mathrm{Al}_{2} \mathrm{O}_{3}$, AlKIT- 1 , and ZSM-5, in HDS of DBT was evaluated. The results are shown in Fig. 8.

Fig. 8 shows that the order of the desulfurization rates of the catalysts is $\mathrm{CoMo} / \mathrm{ZK}-1(40)>\mathrm{CoMo} / \mathrm{ZK}-1(30)>\mathrm{CoMo} / \gamma-\mathrm{Al}_{2} \mathrm{O}_{3}$ $>$ CoMo/ZSM-5 > CoMo/Mix > CoMo/AlKIT-1. The catalysts supported on ZK-1 give the best catalytic performance, especially when the $\mathrm{Si} / \mathrm{Al}$ ratio is 40 . These results indicate that ZK-1 effectively combines the superior acidic properties of ZSM-5 building units and the mesoporous structure of KIT-1. ZK-1 provides a larger surface area and promotes the dispersion of Co and Mo phases on the support. Suitable interactions between the Co and Mo phases and the support improve reduction and sulfidation of the metallic phases. ZK-1 consists of a mesoporous KIT-1 structure containing ZSM-5 building units. Rozanska et al. [32] reported that zeolites alone can hydrodesulfurize DBT through direct sulfur atom elimination and hydrogenation desulfurization routes. Shen's group [33,34] prepared a NiW-based catalyst containing USY, which showed high activity in HDS of 4,6-DMDBT and fluid catalytic cracking of diesel oil. The presence of ZSM-5 building units enhances the hydrothermal stability and acidity of mesoporous molecular sieves compared with those of A1KIT-1 [21,22]. CoMo/ZK-1

\section{Table 2}

Average lengths $(\bar{L})$ and average stacking layer numbers $(\bar{N})$ of $\mathrm{MoS}_{2}$ in series of CoMo sulfided catalysts.

\begin{tabular}{lccc}
\hline Catalyst & $\bar{L}(\mathrm{~nm})$ & $\bar{N}$ & $f_{\text {Mo }}$ \\
\hline CoMo/ZK-1(30) & 4.03 & 2.51 & 0.27 \\
CoMo/ZK-1(40) & 3.88 & 2.73 & 0.28 \\
CoMo/ $-\mathrm{Al}_{2} \mathrm{O}_{3}$ & 6.43 & 3.32 & 0.20 \\
CoMo/AlKIT-1 & 4.66 & 2.78 & 0.24 \\
CoMo/ZSM-5 & 7.67 & 4.54 & 0.16 \\
CoMo/Mix & 5.42 & 3.17 & 0.21 \\
\hline
\end{tabular}




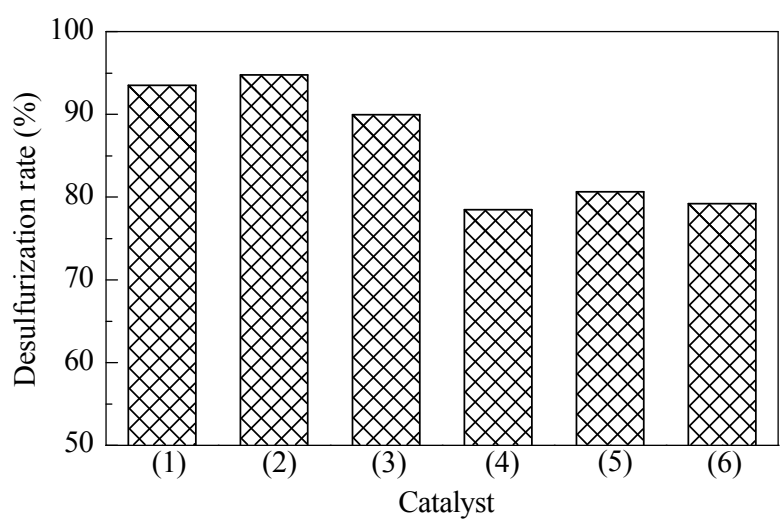

Fig. 8. HDS of DBT over the catalysts. (1) CoMo/ZK-1(30); (2) CoMo/ZK-1(40); (3) CoMo/ $\gamma-\mathrm{Al}_{2} \mathrm{O}_{3}$; (4) CoMo/AlKIT-1; (5) CoMo/ZSM-5; (6) CoMo/Mix. Reaction conditions: temperature $320^{\circ} \mathrm{C}$, pressure 3 MPa, weight hourly space velocity $5 \mathrm{~h}^{-1}$, time on stream $60 \mathrm{~h}$.

has a larger amount of weak acid sites than the other catalysts; this decreases the hydrocracking activity and increases the HDS activity. Furthermore, micro-mesoporous channel connectivity is a major factor in significantly improving the catalytic activity.

The desulfurization rate over the catalyst supported on $\gamma-\mathrm{Al}_{2} \mathrm{O}_{3}$ is $90 \%$, indicating that it is a suitable support for HDS catalysts. The activity of CoMo/ZSM-5 is lower than those of CoMo/ZK-1 and CoMo $/ \gamma-\mathrm{Al}_{2} \mathrm{O}_{3}$. The reasons are as follows. (1) The small pore channels in the ZSM-5 zeolite hinder access of the reactant molecules to the active sites. (2) The lower external surface area $\left(34 \mathrm{~m}^{2} / \mathrm{g}\right)$ induces polymerization of the $\mathrm{MoO}_{3}$ phases, which leads to the formation of more large stacked $\mathrm{MoS}_{2}$ crystallites, as shown in the HRTEM micrographs. The lower $f_{\mathrm{Mo}}(0.16)$ of CoMo/ZSM-5 means that its DBT HDS activity is lower than those of the other samples.

\section{Conclusions}

Micro-mesoporous ZK-1 molecular sieves were used as supports for HDS catalysts. The characterization results show that CoMo/ZK-1 catalysts have large surface areas, large pore volume, and micro-mesoporous structure; these promote the dispersion of Co and Mo oxide phases on the ZK-1 support. CoMo/ZK-1 has a larger number of acidic sites than CoMo/AlKIT-1, which have the same $\mathrm{Si} / \mathrm{Al}$ ratio. Suitable interac- tions between the Co and Mo phases and ZK-1 promote reduction and sulfidation of the metallic phases. HRTEM images show shorter lengths, lower stacking numbers, and larger $f_{\text {Mo }}$ values for $\mathrm{MoS}_{2}$ particles in CoMo/ZK-1, confirming that CoMo/ZK-1 has better $\mathrm{MoS}_{2}$ dispersion and more active edge sites. The catalytic activity of the catalysts supported on ZK-1 in HDS of DBT is higher than that of catalysts supported on $\gamma-\mathrm{Al}_{2} \mathrm{O}_{3}$, AlKIT-1, ZSM-5, and a mixture of AlKIT-1 and ZSM-5.

\section{References}

[1] C. S. Song, Catal. Today, 2003, 86, 211.

[2] H. Topsee, B. S. Clausen, Appl. Catal., 1986, 25, 273.

[3] X. C. Fang, R. Guo, C. M. Yang, Chin. J. Catal., 2013, 34, 130.

[4] Z. B. Wei, Q. Xin, Chin. J. Catal., 1994, 15, 161

[5] S. Y. Ren, J. Li, B. Feng, Y. D. Wang, W. C. Zhang, G. M. Wen, Z. H. Zhang, B. J. Shen, Catal. Today, 2015, doi: 10.1016/j.cattod.2015. 06.023.

[6] M. V. Landau, L. Vradman, M. Herskowitz, Y. Koltypin, A. Gedanken, J. Catal., 2001, 201, 22.

[7] X. Li, F. Zhou, A. J. Wang, L. Y. Wang, Y. K. Hu, Ind. Eng. Chem. Res., 2009, 48, 2870.

[8] K. Soni, K. C. Mouli, A. K. Dalai, J. Adjaye, Catal. Lett., 2010, 136, 116.

[9] R. Nava, A. Infantes-Molina, P. Castano, R. Guil-Lopez, B. Pawelec, Fuel, 2011, 90, 2726.

[10] K. Soni, B. S. Rana, A. K. Sinha, A. Bhaumik, M. Nandi, M. Kumar, G. M. Dhar, Appl. Catal. B, 2009, 90, 55.

[11] Y. H. Yue, Y. Sun, Z. Gao, Catal. Lett., 1997, 47, 167.

[12] Z. D. Huang, W. Bensch, L. Kienle, S. Fuentes, G. Alonso, C. Ornelas, Catal. Lett., 2009, 127, 132.

[13] R. Ryoo, J. M. Kim, C. H. Ko, C. H. Shin, J. Phys. Chem., 1996, 100, 17718.

[14] F. Zhou, X. Li, A. J. Wang, L. Y. Wang, X. D. Yang, Y. K. Hu, Catal. Today, 2010, 150, 218.

[15] S. Q. Zeng, J. Blanchard, M. Breysse, Y. H. Shi, X. T. Su, H. Nie, D. D. Li, Appl. Catal. A, 2006, 298, 88.

[16] M. Choi, H. S. Cho, R. Srivastava, C. Venkatesan, D. H. Choi, R. Ryoo, Nat. Mater., 2006, 5, 718.

[17] D. Q. Zhang, A. J. Duan, Z. Zhao, C. M. Xu, J. Catal., 2010, 274, 273.

[18] T. S. Li, A. J. Duan, Z. Zhao, B. J. Liu, G. Y. Jiang, J. Liu, Y. C. Wei, H. F. Pan, Fuel, 2014, 117, 974.

[19] Y. Y. Sun, R. Prins, Angew. Chem. Int. Ed., 2008, 47, 8478.

[20] L. P. Liu, G. Xiong, X. S. Wang, J. Cai, Z. Zhao, Microporous Mesoporous Mater., 2009, 123, 221.

\section{Graphical Abstract}

Chin. J. Catal., 2016, 37: 412-419 doi: 10.1016/S1872-2067(15)61017-8

Preparation of highly dispersed desulfurization catalysts and their catalytic performance in hydrodesulfurization of dibenzothiophene

Liang Hao, Guang Xiong, Liping Liu*, Huayun Long, Fengying Jin, Xiangsheng Wang

Dalian University of Technology

Micro-mesoporous ZK-1 molecular sieves were used as supports for HDS catalysts. CoMo/ZK-1 catalysts had high surface area and hierarchical porous structure. CoMo/ZK-1 had the highest catalytic activity in HDS of DBT.

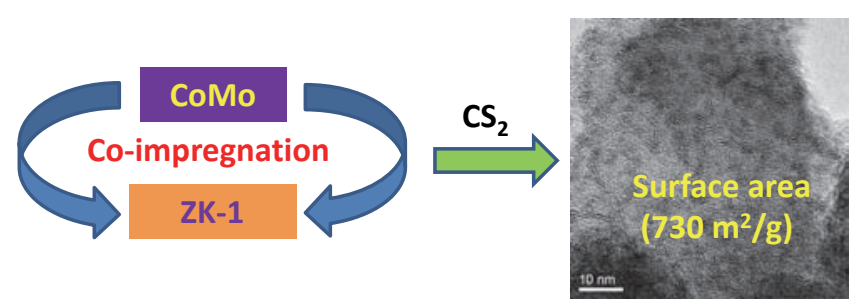


[21] L. P. Liu, F. Y. Jin, G. Xiong, H. Y. Long, X. S. Wang, J. Porous Mater., 2013, 20, 637.

[22] D. H. Olson, G. T. Kokotailo, S. L. Lawton, W. M. Meier, J. Phys. Chem., 1981, 85, 2238.

[23] R. Nava, B. Pawelec, J. Morales, R. A. Ortega, J. L. G. Fierro, Microporous Mesoporous Mater., 2009, 118, 189.

[24] S. Damyanova, A. Spojakina, K. Jiratova, Appl. Catal. A, 1995, 125, 257.

[25] D. C. Vermaire, P. C. Van Berge, J. Catal., 1989, 116, 309.

[26] G. Xiong, C. Li, Z. C. Feng, P. L. Ying, Q. Xin, J. K. Liu, J. Catal., 1999, $186,234$.

[27] J. Ramirez, R. Contreras, P. Castillo, T. Klimova, R. Zarate, R. Luna, Appl. Catal. A, 2000, 197, 69.
[28] Ch. Papadopoulou, J. Vakros, H. K. Matralis, G. A. Voyiatzis, Ch. Kordulis, J. Colloid. Interface. Sci., 2004, 274, 159.

[29] H. K. Matralis, Ch. Papadopoulou, A. Lycourghiotis, Appl. Catal. A, 1994, 116, 221.

[30] T. F. Hayden, J. A. Dumesic, J. Catal., 1987, 103, 366.

[31] A. J. Duan, T. S. Li, Z. Zhao, B. J. Liu, X. F. Zhou, G. Y. Jiang, J. Liu, Y. C. Wei, H. F. Pan, Appl. Catal. B, 2015, 165, 763.

[32] X. Rozanska, X. Saintigny, R. A. van Santen, S. Clémendot, F. Hutschka, J. Catal., 2002, 208, 89.

[33] L. Wang, B. J. Shen, F. Fang, F. C. Wang, R. Tian, Z. H. Zhang, L. S. Cui, Catal. Today, 2010, 158, 343.

[34] Y. D. Wang, B. J. Shen, J. C. Li, B. Feng, X. H. Li, S. Y. Ren, Q. X. Guo, Fuel Process Technol., 2014, 128, 166.

\title{
高分散加氢脱硫催化剂制备及其对二苯并噻吩的催化性能
}

\author{
郝 堶, 熊 光, 刘丽萍*，龙化云，靳凤英，王祥生 \\ 大连理工大学化工学院精细化工国家重点实验室, 辽宁大连 116024
}

摘要: 近年来, 柴油发动机产生的废气污染已成为一个严重问题, 环境法规对燃油中的硫含量限制越来越严格. 因此, 开发 高效的深度加氢脱硫催化剂成为当今的热门课题之一. 在柴油馏分中, 由于存在空间位阻作用, 二苯并噻吩(DBT)及其烷基 取代的衍生物是最难脱除的. 传统的加氢脱硫(HDS)催化剂通常是将活性金属担载在 $\gamma-\mathrm{Al}_{2} \mathrm{O}_{3}$ 上. 近年来, 介孔材料如 MCM-41, SBA-15, HMS, KIT-1和KIT-6等也被用作加氢脱硫催化剂载体, 其大的比表面积有利于活性组分分散, 大的规则孔 径有利于反应物和产物扩散. 其中, KIT-1介孔分子笁具有三维短蠕虫状介孔结构和大的比表面积, 其酸性和水热稳定性都 高于MCM-41. 然而,由于无定形的孔壁使得介孔分子笁的酸性和水热稳定性较差, 限制了其在石油化工领域的应用. 而介 微孔复合分子笁兼具了微孔分子笁酸性强、水热稳定性好和介孔分子笁的孔道优势, 因此一经出现就引起了研究者广泛关 注. 有研究认为, 增加载体酸性有利于加氢及促进 $\mathrm{C}-\mathrm{S}$ 键氢解反应. 载体中的微孔可高效吸附氢分子, 降低HDS过程所需的 温度和压力, 实现温和条件下燃油超深度脱硫. 目前, 已有研究者将Y-MCM-41, 介孔ZSM-5及Beta-KIT-6等多级孔分子笚用 作催化剂载体, 并进行了加氢脱硫性能研究, 取得了良好效果. 我们曾利用双模板剂一步晶化法水热合成了介微孔复合分 子篮ZK-1. 该分子篮既具有与KIT-1相似的短蠕虫状三维介孔孔道, 又具有ZSM- 5 的微孔结构. 其介孔孔径为 $2.7 \mathrm{~nm}$, 微孔孔 径为 $0.6 \mathrm{~nm}$. 该分子篮具有良好的水热稳定性和较高的酸性.

本文在上述研究基础上, 以不同硅铝比的ZK-1为载体通过过量浸渍法担载 $\mathrm{Co}, \mathrm{Mo}$ 活性组分制备了 $\mathrm{CoMo} / \mathrm{ZK}-1(\mathrm{Si} / \mathrm{Al}=$ 30 )和 CoMo/ZK-1 ( $\mathrm{Si} / \mathrm{Al}=40$ ) 催化剂, 并以相同方法制备了 $\mathrm{CoMo} / \gamma-\mathrm{Al}_{2} \mathrm{O}_{3}, \mathrm{CoMo} / \mathrm{AlKIT}-1, \mathrm{CoMo} / \mathrm{ZSM}-5$ 和CoMo/Mix (等量 的ZSM-5 和AIKIT-1混合物)催化剂作为对比. 催化剂的 $\mathrm{N}_{2}$ 吸附和 $\mathrm{NH}_{3}$ 程序升温脱附表征结果表明, CoMo/ZK-1 具有高于其 他催化剂的比表面积(约 $700 \mathrm{~m}^{2} / \mathrm{g}$ ) 和介微孔结构, 介孔孔径和微孔孔径分别为 $2.3 \mathrm{~nm}$ 和 $0.6-1 \mathrm{~nm}$. CoMo/ZK-1的酸量大于相 同硅铝比的CoMo/AlKIT-1, 这是由于ZK-1的介孔孔壁上含有沸石结构单元. 通过 $\mathrm{H}_{2}$ 程序升温还原表征可知, CoMo/ZK-1的 高温氢耗峰面积较 $\mathrm{CoMo} / \gamma-\mathrm{Al}_{2} \mathrm{O}_{3}$ 和 CoMo/ZSM- 5 相比明显减小, 表明在 $\mathrm{CoMo} / \mathrm{ZK}-1$ 上难还原的组分数量减少, 载体与金属 之间的相互作用减弱, 这有利于金属组分的还原和硫化. 紫外-可见漫反射光谱表征结果表明, 在ZSM- 5 表面形成了大量的 聚合态氧化钼物种, 这是由于载体表面积小,金属组分分散不均匀. $\mathrm{Co}_{2} \mathrm{AlO}_{4}$ 或 $\mathrm{Co}_{2} \mathrm{SiO}_{4}$ 相的出现是由于载体与金属间存在 较强的相互作用. 以ZK-1和AIKIT-1为载体的催化剂则避免了该情况的发生. 从高分辨透射电镜照片可知, $\mathrm{MoS}_{2}$ 在ZK-1表 面分散很均匀, 其堆垛层数(2.5-2.7层)和片晶长度(3.9-4.0 nm) 都达到较理想的数值, 有利于形成更多的Co-Mo-S(II)活性相.

以二苯并噻吩为模型化合物, 采用固定床反应器考察了上述6种催化剂的加氢脱硫活性. 催化剂的脱硫率从高到低依 次为: $\mathrm{CoMo} / \mathrm{ZK}-1(40)>\mathrm{CoMo} / \mathrm{ZK}-1(30)>\mathrm{CoMo} / \gamma-\mathrm{Al}_{2} \mathrm{O}_{3}>\mathrm{CoMo} / \mathrm{ZSM}-5>\mathrm{CoMo} / \mathrm{Mix}>\mathrm{CoMo} / \mathrm{AlKIT}-1$. 在较温和的反应条 件 $\left(320^{\circ} \mathrm{C}, 3 \mathrm{MPa}, \mathrm{WHSV}=5 \mathrm{~h}^{-1}\right)$ 下, CoMo/ZK- 1 对DBT的脱硫率达到 $93 \%$ 以. 其原因主要是: (1) ZK-1的大比表面积使Co, Mo活性组分高度分散在载体表面; (2) 载体与金属之间较适中的相互作用有利于活性组分的还原与硫化; (3) ZK-1含有的 沸石结构单元使其比AlKIT-1具有更多的酸中心, 有利于提高HDS反应活性.

关键词: 介微孔复合分子篮; ZK-1; 加氢脱硫; 二苯并噻吩

收稿日期: 2015-10-15. 接受日期: 2015-11-12. 出版日期: 2016-03-05.

*通讯联系人. 电话/传真: (0411)84986139; 电子信箱: liuliping@dlut.edu.cn

基金来源：国家自然科学基金(21206017).

本文的英文电子版由Elsevier出版社在ScienceDirect上出版(http://www.sciencedirect.com/science/journal/18722067). 